Jurnal Gizi Klinik Indonesia

Vol. 17 No. 1, Juli 2020 (23-33)

ISSN 1693-900X (Print), ISSN 2502-4140 (Online)

Tersedia online di https://jurnal.ugm.ac.id/jgki

DOI: https://doi.org/10.22146/ijcn.49696

\title{
Faktor sosial, ekonomi, dan pemanfaatan posyandu dengan kejadian stunting balita keluarga miskin penerima PKH di Palembang
}

Social, economic factors, and utilization of posyandu towards stunting among toddlers of poor families of PKH recipients in Palembang

Nur Farida Rahmawati, Nur Alam Fajar, Haerawati Idris

Magister Kesehatan Masyarakat, Fakultas Kesehatan Masyarakat, Universitas Sriwijaya, Palembang

\begin{abstract}
Background: Stunting is a nutritional problem caused by chronic malnutrition. Stunting can result in decreased concentration, memory damage, decreased learning and school performance, decreased cognitive function, impaired motor development, and has a long-term impact on reducing productivity, thus inhibiting economic growth and causing intergenerational poverty. Stunting can be influenced by social, economic, and access to health services factors. Objective: To analyze the correlation of social, economic, and utilization of integrated services post (pos pelayanan terpadu/posyandu) with the incidence of stunting of under-fives in poor families in Palembang. Methods: This study used quantitave method with a cross-sectional design in March-April 2019. Population were toddlers aged 24-59 months from poor families in Palembang, with the criteria receiving the cash transfer programme from the Indonesian Government, called Program Keluarga Harapan (PKH). Samples were 100 people were chosen by proportional sampling. Data was analyzed by using Chi-Square test and regression logistic test. Results: The proportion of stunting among toddlers in poor families of PKH recipients in Palembang was 29\%. Multiple logistic regression test shows 4 (four) independent variables have significant correlation to the incidence of stunting simultaneously. Those variable are maternal education ( $p=0.003$, OR $=7.278,95 \%$ CI: 1.928-27.474), birth order $(p=0.013$, OR $=0.144,95 \%$ CI: 0.031-0.664), number of family members ( $p=0.013$, OR=10.809, 95\% CI: 1.639-71.278), irregular utilization of Posyandu ( $p=0.041$, OR=3.524, 95\% CI: 1.055-11.768), and never using Posyandu ( $p=0.019$, OR=5.282, 95\% CI: 1.313-21.239). Low maternal education, huge family members (more than 4), irregularly and never use Posyandu increase risk of stunting 7.2 times, 10.8 times, 3.5, and 5.2 times, otherwise first or second birth order was a protective factor of stunting. Conclusions: Maternal education and utilization of Posyandu are protective factors, meanwhile huge family member (more than 4) and third or more birth order can increase stunting incidence among toddlers of poor families of $P K H$ recipient.
\end{abstract}

KEYWORDS: economic; poverty; social; stunting; utilization of posyandu

\begin{abstract}
ABSTRAK
Latar belakang: Stunting merupakan masalah gizi akibat kekurangan gizi secara kronis. Stunting dapat menyebabkan penurunan konsentrasi, kerusakan memori, penurunan daya belajar dan prestasi sekolah, penurunan fungsi kognitif, dan gangguan perkembangan motorik anak, serta berdampak jangka panjang pada penurunan produktivitas sehingga menghambat pertumbuhan ekonomi dan menyebabkan kemiskinan antargenerasi. Kejadian stunting dapat dipengaruhi oleh faktor sosial, ekonomi, dan akses terhadap pelayanan kesehatan. Tujuan: Penelitian ini bertujuan menganalisis hubungan faktor sosial, ekonomi, dan pemanfaatan pos pelayanan terpadu (posyandu) dengan kejadian stunting balita keluarga miskin penerima Program Keluarga Harapan (PKH) di Kota Palembang. Metode: Penelitian kuantitatif dengan menggunakan desain cross-sectional pada bulan Maret-April 2019. Populasi penelitian adalah seluruh balita usia 24-59 bulan dari keluarga miskin di Kota Palembang dengan kriteria penerima PKH. Sampel berjumlah 100 orang yang diambil dengan cara proportional sampling. Analisis data menggunakan uji Chi-Square dan uji regresi logistik. Hasil: Proporsi stunting balita keluarga miskin penerima PKH di Kota Palembang sebesar 29\%. Hasil uji regresi logistik ganda menunjukkan ada empat variabel yang secara simultan berhubungan signifikan terhadap kejadian stunting balita, yaitu
\end{abstract}

Korespondensi: Nur Farida Rahmawati, Magister Kesehatan Masyarakat, Fakultas Kesehatan Masyarakat, Universitas Sriwijaya, Jl. Palembang - Indralaya Ogan Ilir Sumatera Selatan, Indonesia,e-mail: nurfarida 08@yahoo.com

Cara sitasi: Rahmawati NF, Fajar NA, Idris H. Faktor sosial, ekonomi, dan pemanfaatan posyandu dengan kejadian stunting balita keluarga miskin penerima PKH di Palembang. Jurnal Gizi Klinik Indonesia. 2020;17(1):23-33. doi: 10.22146/ijen.49696 
pendidikan ibu ( $\mathrm{p}=0,003$; OR=7,278; 95\% CI: 1,928-27,474); urutan kelahiran ( $\mathrm{p}=0,013 ; \mathrm{OR}=0,144 ;$ 95\% CI: 0,031-0,664); jumlah anggota keluarga $(p=0,013 ; \mathrm{OR}=10,809 ; 95 \% \mathrm{CI}: 1,639-71,278)$; serta pemanfaatan posyandu tidak rutin $(\mathrm{p}=0,041 ; \mathrm{OR}=3,524$; 95\% CI: 1,055-11,768) dan tidak pernah ( $\mathrm{p}=0,019 ; \mathrm{OR}=5,282 ; 95 \% \mathrm{CI}: 1,313-21,239)$. Ibu berpendidikan rendah, jumlah anggota keluarga banyak (lebih dari 4 orang), tidak rutin atau tidak pernah memanfaatan posyandu dapat meningkatkan risiko terjadinya stunting sebesar 7,2 kali, 10,8 kali, 3,5 dan 5,2 kali sedangkan urutan kelahiran pertama dan kedua merupakan faktor protektif terjadinya stunting. Simpulan: Pendidikan ibu dan pemanfaatan posyandu merupakan faktor protektif, sementara jumlah anggota keluarga banyak (lebih dari 4 orang) dan anak urutan ketiga dan selanjutnya meningkatkan risiko terjadinya stunting balita pada keluarga miskin penerima PKH.

KATA KUNCI: ekonomi; kemiskinan; sosial; stunting; pemanfaatan posyandu

\section{PENDAHULUAN}

Saat ini, stunting telah menjadi masalah prioritas global yang harus diatasi (1). Berbagai penelitian menemukan bahwa stunting berhubungan dengan penurunan konsentrasi, kerusakan memori, penurunan daya belajar, menurunkan prestasi sekolah dan fungsi kognitif, serta gangguan perkembangan motorik pada anak $(2,3)$. Dampak stunting jangka panjang dapat menghambat pertumbuhan ekonomi dan menurunkan produktivitas pasar kerja sehingga mengakibatkan kehilangan 11\% gross domestic product (GDP) serta mengurangi pendapatan pekerja dewasa hingga 20\%. Stunting juga dapat berkontribusi pada melebarnya kesenjangan/inequality, mengurangi $10 \%$ dari total pendapatan seumur hidup, dan menyebabkan kemiskinan antargenerasi (4).

Besarnya masalah stunting ditandai dengan jumlah anak stunting di dunia sebanyak 155 juta pada tahun 2016 (5). Di Indonesia, berdasarkan hasil Riset Kesehatan Dasar (Riskesdas) tahun 2018, prevalensi anak balita stunting sebesar 30,8\%. Angka ini menunjukkan penurunan prevalensi stunting dibandingkan dengan hasil Riskesdas tahun 2013 sebesar 37,2\% (6). Meskipun demikian, persentase stunting di atas 30\% masih tergolong prevalensi tinggi dari masalah kesehatan masyarakat (7). Prevalensi stunting balita di Provinsi Sumatera Selatan berdasarkan hasil Riskesdas tahun 2018 sebesar 31,6\% yang meningkat jika dibandingkan data Pemantauan Status Gizi (PSG) pada tahun 2017 sebesar 22,8\% (8), sedangkan prevalensi stunting balita di Kota Palembang pada tahun 2017 sebesar 27,4\% (9). Kejadian stunting di masyarakat mengambarkan kegagalan untuk mencapai potensi genetik tinggi badan serta prediktor perkembangan lainnya, termasuk kognitif dan potensi ekonomi masa depan (5).
Stunting pada balita merupakan indikator terbaik pertumbuhan anak dan merefleksikan ketidaksetaraan sosial (social inequalities) (1). Stunting merupakan konsekuensi dari beberapa faktor yang sering dikaitkan dengan kemiskinan, termasuk gizi, kesehatan, sanitasi, dan lingkungan (10). Penyebab stunting sangat beragam dan kompleks, tetapi secara umum dikategorikan menjadi tiga faktor yaitu akar masalah (basic causes), yang terdiri dari faktor ekonomi, sosial, politik; penyebab tidak langsung (underlying causes) yang terdiri dari faktor ketersediaan pangan, pola asuh, dan pelayanan kesehatan; dan penyebab langsung (immediate causes) yang terdiri dari faktor asupan zat gizi dan penyakit infeksi (11).

Faktor sosial yang sering dikaitkan dengan kejadian stunting adalah pendidikan dan pekerjaan orang tua, jumlah anak balita, jarak kelahiran, urutan kelahiran, dan jumlah anggota keluarga (12-17). Selain itu, faktor ekonomi yang mempengaruhi kejadian stunting adalah pendapatan dan pengeluaran untuk pangan (13). Pendapatan akan berpengaruh terhadap pemenuhan zat gizi keluarga dan kesempatan dalam mengikuti pendidikan formal. Kemiskinan dalam waktu yang lama dapat mengakibatkan keluarga tidak mampu memenuhi kebutuhan pangan dengan kuantitas dan kualitas yang baik. Penurunan kualitas konsumsi pangan yang ditandai dengan keterbatasan pembelian pangan sumber protein, vitamin, dan mineral akan berakibat pada kekurangan gizi, baik zat gizi makro maupun mikro (14).

Masalah kemiskinan juga akan berdampak pada akses masyarakat yang kurang terhadap pemenuhan kebutuhan pangan maupun pelayanan kesehatan (18). Salah satu jenis pelayanan kesehatan berbasis masyarakat adalah pos pelayanan terpadu (Posyandu). Posyandu mempunyai manfaat untuk memantau pertumbuhan balita, pemberian vitamin A, imunisasi, stimulasi 
tumbuh kembang, serta edukasi tentang gizi dan kesehatan. Rumah tangga balita yang memanfaatkan pelayanan kesehatan, lebih banyak yang memiliki balita berstatus gizi baik dan angka kesakitan lebih rendah jika dibandingkan dengan rumah tangga yang tidak memanfaatkan pelayanan kesehatan (19).

Meskipun kemiskinan sering dikaitkan dengan kejadian stunting, ditemukan fenomena yang menarik bahwa pada populasi keluarga sangat miskin ternyata terdapat balita dengan status gizi baik dan gizi lebih atau yang disebut penyimpangan positif (positive deviance) (20). Positive deviance secara khusus digunakan untuk menjelaskan faktor-faktor yang berpengaruh terhadap pertumbuhan atau status gizi yang baik pada anak-anak yang hidup dalam keluarga miskin di lingkungan miskin, padahal sebagian besar anak lain mengalami gangguan pertumbuhan dan gizi kurang (21).

Penelitian stunting pada balita telah banyak dilakukan, tetapi penelitian yang secara khusus dilakukan pada populasi keluarga miskin masih jarang. Tujuan penelitian ini adalah mengetahui seberapa besar prevalensi kejadian stunting pada balita keluarga miskin di Kota Palembang, serta menganalisis keterkaitannya dengan faktor sosial, ekonomi, dan pemanfaatan Posyandu sehingga dapat menjadi masukan bagi pengambil kebijakan untuk menentukan langkah yang konkret dalam mengentaskan masalah stunting pada keluarga miskin.

\section{BAHAN DAN METODE}

\section{Desain dan subjek}

Jenis penelitian ini merupakan penelitian observasional dengan metode kuantitatif menggunakan desain cross-sectional. Penelitian ini dilaksanakan di Kota Palembang pada bulan Maret hingga April 2019. Populasi penelitian ini seluruh balita berusia 24 - 59 bulan pada keluarga miskin di Kota Palembang sebanyak 106.971 balita. Jumlah sampel dihitung menggunakan rumus Lemeshow dengan nilai distribusi normal baku $\left(Z_{1-\alpha / 2}\right)$ $(\mathrm{Z}=1,96$ untuk $\mathrm{a}=0,05)$; proporsi $(\mathrm{p})$ pada populasi sebesar 0,3 berdasarkan Riskesdas 2018 (6); dan kesalahan absolut yang dapat ditoleransi (e) sebesar 9\% sehingga diperoleh sampel minimal sebanyak 100 balita. Sampel diambil dengan cara proportional sampling berdasarkan jumlah balita pada 41 Puskesmas di 18 kecamatan di Kota Palembang. Kriteria inklusi yaitu keluarga miskin yang memiliki Kartu Program Keluarga Harapan (PKH), tinggal di wilayah Kota Palembang, dan bersedia menjadi responden, sedangkan kriteria eksklusi adalah balita yang memiliki saudara kandung yang menjadi sampel penelitian, balita memiliki cacat fisik sehingga sulit dilakukan pengukuran antropometri, ibu tidak bisa berkomunikasi efektif, dan tidak hadir saat penelitian. Penelitian ini telah mendapatkan persetujuan etik dari Komisi Etik Penelitian Kesehatan Fakultas Kesehatan Masyarakat Universitas Sriwijaya dengan nomor: 10/ UN9.1.10/KKE/2019.

\section{Pengumpulan dan pengukuran data}

Variabel terikat adalah kejadian stunting, sedangkan variabel bebas adalah faktor sosial (pendidikan orang tua, pekerjaan ayah, status pekerjaan ibu, jumlah balita, jarak kelahiran, urutan kelahiran, dan jumlah anggota keluarga), faktor ekonomi (pengeluaran pangan), dan pemanfaatan posyandu.

Stunting. Data kejadian stunting diperoleh dari perbandingan tinggi badan balita dengan $z$-score berdasarkan umur dan jenis kelamin pada Keputusan Menteri Kesehatan RI No. 1995/MENKES/SK/XII/2010 tentang standar antropometri penilaian status gizi anak. Kejadian stunting dikategorikan menjadi stunting jika tinggi badan menurut umur (TB/U) kurang dari -2 SD dan normal jika TB/U lebih dari atau sama dengan -2 SD.

Faktor sosial. Data faktor sosial terdiri dari pendidikan orang tua, yaitu tingkat pendidikan formal terakhir ayah dan ibu balita yang dikategorikan menjadi rendah (lebih rendah dari sekolah menengah atas atau SMA) dan tinggi (minimal SMA); pekerjaan ayah dikategorikan menjadi pekerjaan tetap dan tidak tetap; status pekerjaan ibu dikategorikan menjadi bekerja dan tidak bekerja atau ibu rumah tangga; jumlah balita dalam keluarga dikategorikan menjadi banyak ( $>1$ balita) dan sedikit (1 balita); jarak kelahiran yaitu selisih atau interval bulan antara kelahiran balita subjek penelitian dengan saudara terdekat, dikategorikan menjadi dekat ( $<24$ bulan) dan tidak dekat ( $\geq 24$ bulan); urutan kelahiran adalah urutan kelahiran balita dibandingkan dengan 
saudara kandung di dalam keluarga yang dikategorikan menjadi anak ke 3 atau lebih dan anak pertama atau kedua; dan jumlah anggota keluarga yaitu jumlah anggota keluarga yang tinggal dalam satu rumah dan hidup atau makan dari sumber pendapatan yang sama, dikategorikan menjadi banyak ( $>4$ orang) dan sedikit ( $\leq 4$ orang).

Faktor ekonomi. Data faktor ekonomi dilihat dari pengeluaran pangan, yaitu proporsi jumlah uang yang dikeluarkan untuk konsumsi pangan oleh keluarga per bulan dibandingkan dengan total pengeluaran sebulan, dikategorikan menjadi tinggi jika lebih atau sama dengan $60 \%$ dan rendah jika kurang dari 60\%.

Pemanfaatan posyandu. Data pemanfaatan posyandu diperoleh dari jumlah kunjungan balita ke posyandu dalam 6 bulan terakhir yang dikategorikan menjadi tidak pernah atau tidak rutin jika kunjungan sebanyak 1-5 kali kunjungan, dan rutin jika melakukan kunjungan setiap bulan (6 kali).

Penelitian ini menggunakan beberapa instrumen antara lain kuesioner, alat tulis, alat perekam, kamera, microtoise, panduan wawancara, dan checklist observasi. Alur penelitian yaitu dengan penentuan subjek penelitian yang memenuhi kriteria inklusi dan eksklusi, kemudian dilakukan penjelasan prosedur penelitian dan persetujuan penelitian (informed consent). Selanjutnya, dilakukan pengukuran status gizi balita dengan menghitung usia balita, pengukuran tinggi badan, penentuan status gizi balita berdasarkan TB/U, dan wawancara dengan ibu balita.

\section{Analisis data}

Analisis data dilakukan secara univariat, bivariat, dan multivariat. Analisis bivariat menggunakan uji ChiSquare, sedangkan analisis multivariat menggunakan uji regresi logistik.

\section{HASIL}

Hasil analisis menunjukkan bahwa proporsi stunting pada populasi keluarga miskin di Kota Palembang sebanyak 29,0\%. Berdasarkan karakteristik responden pada Tabel 1, dapat diketahui bahwa mayoritas ayah (62\%) dan ibu balita (65\%) memiliki tingkat pendidikan rendah, pekerjaan ayah tidak tetap $(82 \%)$, ibu tidak
Tabel 1. Karakteristik responden $(n=100)$

\begin{tabular}{|c|c|}
\hline $\begin{array}{r}\text { Variabel } \\
\end{array}$ & $\mathbf{n}$ \\
\hline \multicolumn{2}{|l|}{ Pendidikan ayah } \\
\hline Rendah $(<$ SMA $)$ & 62 \\
\hline Tinggi ( $\geq$ SMA) & 38 \\
\hline \multicolumn{2}{|l|}{ Pendidikan ibu } \\
\hline Rendah $(<$ SMA) & 65 \\
\hline Tinggi ( $\geq$ SMA) & 35 \\
\hline \multicolumn{2}{|l|}{ Pekerjaan ayah } \\
\hline Tidak Tetap & 82 \\
\hline Tetap & 18 \\
\hline \multicolumn{2}{|l|}{ Status pekerjaan ibu } \\
\hline Bekerja & 43 \\
\hline Tidak Bekerja & 57 \\
\hline \multicolumn{2}{|l|}{ Jumlah balita } \\
\hline Banyak (> 1) & 27 \\
\hline Sedikit (1) & 73 \\
\hline \multicolumn{2}{|l|}{ Jarak kelahiran (bulan) } \\
\hline Dekat $(<24)$ & 13 \\
\hline Tidak dekat $(\geq 24)$ & 87 \\
\hline \multicolumn{2}{|l|}{ Urutan kelahiran } \\
\hline Anak ke 3 atau lebih & 67 \\
\hline Anak ke 1 atau 2 & 33 \\
\hline \multicolumn{2}{|c|}{ Jumlah anggota keluarga (orang) } \\
\hline Banyak $(>4)$ & 79 \\
\hline Sedikit $(\leq 4)$ & 21 \\
\hline \multicolumn{2}{|l|}{ Pengeluaran pangan $(\%)$} \\
\hline Tinggi $(\geq 60)$ & 21 \\
\hline Rendah $(<60)$ & 79 \\
\hline \multicolumn{2}{|l|}{ Pemanfaatan posyandu } \\
\hline Tidak pernah & 18 \\
\hline Tidak rutin & 36 \\
\hline Rutin & 46 \\
\hline
\end{tabular}

bekerja (57\%), memiliki sedikit anak balita (73\%), jarak kelahiran tidak dekat (87\%), urutan kelahiran 3 atau lebih (67\%), memiliki jumlah anggota keluarga yang banyak (79\%), pengeluaran pangan rendah $(79 \%)$, dan rutin memanfaatkan posyandu ( $46 \%$ ).

Tabel 2 menunjukkan hubungan yang bermakna antara pendidikan ibu dengan kejadian stunting $(\mathrm{p}=0,032$; $\mathrm{OR}=3,512$ ), tetapi tidak ditemukan hubungan antara pendidikan ayah $(\mathrm{p}=0,253)$, pekerjaan ayah $(\mathrm{p}=0,872)$, status pekerjaan ibu $(\mathrm{p}=0,381)$, jumlah balita $(\mathrm{p}=0,407)$, jarak kelahiran $(p=0,751)$, urutan kelahiran $(p=0,974)$, jumlah anggota keluarga $(p=0,161)$, pengeluaran pangan $(p=0,390)$, dan pemanfaatan posyandu $(p=0,157)$ dengan kejadian stunting balita pada keluarga miskin. Sementara itu, Tabel 3 menunjukkan permodelan uji regresi logistik ganda yaitu ada empat variabel bebas 
Tabel 2. Hubungan antara faktor sosial, ekonomi, dan pemanfaatan posyandu dengan kejadian stunting balita pada keluarga miskin

\begin{tabular}{|c|c|c|c|c|c|c|c|c|c|}
\hline \multirow{3}{*}{ Variabel } & \multicolumn{4}{|c|}{ Kejadian stunting } & \multirow{2}{*}{\multicolumn{2}{|c|}{ Total }} & \multirow{3}{*}{$\mathbf{p}$} & \multirow{3}{*}{ OR } & \multirow{3}{*}{$95 \% \mathrm{CI}$} \\
\hline & \multicolumn{2}{|c|}{ Stunting } & \multicolumn{2}{|c|}{ Normal } & & & & & \\
\hline & $\mathbf{n}$ & $\%$ & n & $\%$ & $\mathbf{n}$ & $\%$ & & & \\
\hline \multicolumn{10}{|l|}{ Pendidikan ayah } \\
\hline Rendah & 21 & 33,9 & 41 & 66,1 & 62 & 100 & \multirow[t]{2}{*}{0,253} & \multirow[t]{2}{*}{1,921} & \multirow[t]{2}{*}{$0,750-4,920$} \\
\hline Tinggi & 8 & 21,1 & 30 & 78,9 & 38 & 100 & & & \\
\hline \multicolumn{10}{|l|}{ Pendidikan ibu } \\
\hline Rendah & 24 & 36,9 & 41 & 63,1 & 65 & 100 & \multirow[t]{2}{*}{0,032} & \multirow[t]{2}{*}{3,512} & \multirow[t]{2}{*}{$1,202-10,264$} \\
\hline Tinggi & 5 & 14,3 & 30 & 85,7 & 35 & 100 & & & \\
\hline \multicolumn{10}{|l|}{ Pekerjaan ayah } \\
\hline Tidak tetap & 23 & 28,0 & 59 & 72,0 & 82 & 100 & \multirow[t]{2}{*}{0,872} & \multirow[t]{2}{*}{0,780} & \multirow[t]{2}{*}{$0,262-2,324$} \\
\hline Tetap & 6 & 33,3 & 12 & 66,7 & 18 & 100 & & & \\
\hline \multicolumn{10}{|l|}{ Status pekerjaan ibu } \\
\hline Bekerja & 10 & 23,3 & 33 & 76,7 & 43 & 100 & \multirow[t]{2}{*}{0,381} & \multirow[t]{2}{*}{0,606} & \multirow[t]{2}{*}{$0,247-1,486$} \\
\hline Tidak bekerja & 19 & 33,3 & 38 & 66,7 & 57 & 100 & & & \\
\hline \multicolumn{10}{|l|}{ Jumlah balita } \\
\hline Banyak & 10 & 37,0 & 17 & 63,0 & 27 & 100 & \multirow[t]{2}{*}{0,407} & \multirow[t]{2}{*}{1,672} & $0,653-4,279$ \\
\hline Sedikit & 19 & 26,0 & 54 & 74,0 & 73 & 100 & & & \\
\hline Jarak kelahiran & & & & & & & & & \\
\hline Dekat & 3 & 23,1 & 10 & 76,9 & 13 & 100 & 0,751 & 0,704 & $0,179-2,768$ \\
\hline Tidak dekat & 26 & 29,9 & 61 & 70,1 & 87 & 100 & & & \\
\hline Urutan kelahiran & & & & & & & & & \\
\hline Anak ke $\geq 3$ & 20 & 29,9 & 47 & 70,1 & 67 & 100 & 0,974 & 1,135 & $0,449-2,870$ \\
\hline Anak ke 1-2 & 9 & 27,3 & 24 & 72,7 & 33 & 100 & & & \\
\hline Jumlah anggota ke & & & & & & & & & \\
\hline Banyak & 26 & 32,9 & 53 & 67,1 & 79 & 100 & 0,161 & 2,943 & $0,795-10,901$ \\
\hline Sedikit & 3 & 14,3 & 18 & 85,7 & 21 & 100 & & & \\
\hline Pengeluaran panga & & & & & & & & & \\
\hline Tinggi & 4 & 19,0 & 17 & 81,0 & 21 & 100 & 0,390 & 0,508 & $0,155-1,667$ \\
\hline Rendah & 25 & 31,6 & 54 & 68,4 & 79 & 100 & & & \\
\hline Pemanfaatan posya & & & & & & & & & \\
\hline Tidak pernah & 8 & 44,4 & 10 & 55,6 & 18 & 100 & 0157 & 0,547 & $0,178-1,679$ \\
\hline Tidak Rutin & 7 & 19,4 & 29 & 80,6 & 36 & 100 & $0,15 /$ & 1,812 & $0,642-5,113$ \\
\hline Rutin & 14 & 30,4 & 32 & 69,6 & 46 & 100 & & & \\
\hline
\end{tabular}

Tabel 3. Model akhir regresi logistik

\begin{tabular}{lcccc}
\hline \multicolumn{1}{c}{ Variabel } & B & S.E. & p & OR \\
\hline Pendidikan ibu & 1,985 & 0,678 & 0,003 & 7,278 \\
Urutan kelahiran & $-1,936$ & 0,779 & 0,013 & 0,144 \\
Jumlah anggota keluarga & 2,380 & 0,962 & 0,013 & 10,909 \\
Pemanfaatan posyandu & & & 0,045 & $0,031-0,664$ \\
Pemanfaatan posyandu (tidak rutin) & 1,260 & 0,615 & 0,041 & 3,524 \\
Pemanfaatan posyandu (tidak pernah) & 1,664 & 0,710 & 0,019 & 5,282 \\
Konstanta & $-3,917$ & 1,012 & 0 & $1,055-11,768$ \\
\hline
\end{tabular}

yang secara simultan berhubungan signifikan terhadap kejadian stunting balita $(\mathrm{p}<0,05)$. Variabel tersebut adalah pendidikan ibu $(p=0,003$; OR=7,278; 95\% CI: 1,928$27,474)$; urutan kelahiran $(\mathrm{p}=0,013 ; \mathrm{OR}=0,144 ; 95 \%$
CI: 0,031-0,664); jumlah anggota keluarga $(\mathrm{p}=0,013$; $\mathrm{OR}=10,809$; 95\% CI: 1,639-71,278); dan pemanfaatan posyandu ( $\mathrm{p}=0,041 ; \mathrm{OR}=3,524 ; 95 \% \mathrm{CI}: 1,055-11,768$ dan $\mathrm{p}=0,019$; OR=5,282; 95\% CI: 1,313-21,239). 
Model regresi logistik terakhir ini juga menunjukkan bahwa ibu dengan pendidikan yang rendah memiliki kecenderungan memiliki balita stunting 7,2 kali lebih besar jika dibandingkan dengan ibu yang berpendidikan tinggi setelah dikontrol oleh variabel lain. Selain itu, model tersebut juga menunjukkan bahwa balita dengan urutan kelahiran 1 hingga 2 memiliki kecenderungan mengalami stunting 0,1 kali atau memiliki efek protektif jika dibandingkan dengan anak ketiga atau lebih, sedangkan balita dengan jumlah anggota keluarga banyak (lebih dari 4 orang) memiliki kecenderungan mengalami stunting 10,8 kali lebih besar jika dibandingkan dengan jumlah anggota keluarga sedikit. Lebih lanjut, balita yang tidak rutin dan tidak pernah memanfaatkan posyandu akan memiliki kecenderungan 3,5 dan 5,2 kali mengalami stunting jika dibandingkan balita yang memanfaatkan posyandu.

\section{BAHASAN}

Hasil penelitian ini menunjukkan bahwa proporsi stunting pada balita keluarga miskin di Kota Palembang sebesar 29,0\%. Prevalensi stunting antara 20-29\% menggambarkan adanya masalah kesehatan masyarakat dengan prevalensi sedang (7). Angka ini lebih rendah jika dibandingkan dengan prevalensi stunting nasional sebesar 30,8\% dan prevalensi stunting balita di Provinsi Sumatera Selatan sebesar 31,6\% (6), tetapi lebih tinggi jika dibandingkan dengan hasil Pemantauan Status Gizi Kota Palembang tahun 2017 sebesar 27,4\% (9). Status gizi pada masa yang rentan seperti balita, akan mempengaruhi pertumbuhan fisik, mental, sosial, dan intelektual individu (22).

Studi ini menemukan bahwa pendidikan ibu merupakan variabel yang berhubungan signifikan dengan kejadian stunting balita pada keluarga miskin. Ibu berpendidikan rendah mempunyai kecenderungan akan memiliki anak stunting sebesar 7,2 kali dibandingkan ibu dengan pendidikan tinggi. Hal ini sesuai dengan hasil penelitian yang menemukan bahwa pendidikan ibu berhubungan dengan kejadian stunting di Banjarbaru (23). Hasil penelitian di Brazil, Peru, Colombia, dan Mesir juga menemukan bahwa ibu yang memiliki tingkat pendidikan tinggi dapat menurunkan prevalensi stunting balita (24-26). Ibu memiliki peran penting dalam membentuk kebiasaan makan anak, mulai dari pemilihan bahan makanan, persiapan, pengolahan, dan penyajian serta pemberian makanan kepada balita. Ibu berpendidikan tinggi cenderung lebih baik dalam pemilihan jenis makanan karena mengerti bahwa asupan zat gizi pada balita sangat penting bagi pertumbuhan.

Hasil studi melaporkan bahwa ibu yang memiliki pengetahuan yang baik harus diikuti dengan sikap, keterampilan, dan kemauan, serta praktik yang membawa perbaikan gizi balita (27). Selain itu, ibu berpendidikan tinggi lebih mudah untuk mendapatkan akses informasi mengenai gizi dan kesehatan. Hal ini sejalan dengan hasil review yang menemukan bahwa pendidikan pengasuh yang rendah, terutama pendidikan ibu, berhubungan kuat dengan kejadian stunting (28) dan pendidikan ibu merupakan prediktor terbaik untuk status asuh anak. Pendidikan ibu berhubungan positif dengan kesehatan anak ketika lama sekolah ibu sekitar 8 tahun (29). Hal tersebut selaras dengan program wajib belajar 12 tahun pada pendidikan dasar sampai menengah (SD s/d SMA) yang diterapkan oleh Pemerintah Indonesia sejak bulan Juni 2015. Oleh karena itu, salah satu cara untuk memutus mata rantai stunting dalam jangka panjang yaitu diharapkan calon ibu pada keluarga miskin dapat menempuh pendidikan hingga minimal SMA.

Lebih lanjut, hasil penelitian ini menunjukkan tidak ada hubungan signifikan antara pendidikan ayah, pekerjaan ayah, status pekerjaan ibu, jumlah balita, jarak kelahiran, dan faktor ekonomi (pengeluaran pangan) dengan kejadian stunting. Berdasarkan hasil penelitian, sebagian besar ayah memiliki tingkat pendidikan formal yang rendah, yaitu di bawah SMA. Hasil ini didukung studi sebelumnya yang menemukan hubungan yang tidak signifikan antara tingkat pendidikan ayah dengan kejadian stunting pada anak 1-2 tahun (30) dan balita usia 6-36 bulan (13). Hal ini karena ayah tidak mengambil peran yang dominan dalam keputusan penentuan kebutuhan gizi. Selain itu, adat istiadat di Indonesia menunjukkan bahwa ibu memiliki peran utama dalam mengasuh anak sehingga memberikan dampak yang lebih besar dibandingkan ayah (31).

Demikian juga dengan pekerjaan ayah tidak berhubungan signifikan dengan kejadian stunting. Sebagian besar ayah memiliki pekerjaan tidak tetap dan 
penghasilan tidak pasti yang akan mengakibatkan daya beli rumah tangga rendah. Daya beli makanan yang rendah dapat mengakibatkan ketersediaan makanan tidak dapat dipastikan, baik dari segi kualitas maupun kuantitas sehingga dapat menyebabkan masalah gizi pada anak (32). Hal ini sejalan dengan hasil penelitian yang menemukan bahwa pekerjaan orang tua tidak berhubungan dengan kejadian stunting baduta (33). Sebaliknya, sebuah penelitian di Turki menemukan hubungan signifikan antara ayah yang tidak bekerja dengan kejadian stunting (34). Bahkan, ayah yang tidak bekerja akan meningkatkan risiko kejadian stunting berat (severe stunting) (14).

Masa balita merupakan masa tumbuh kembang yang pesat. Strategi intervensi sedini mungkin harus diambil untuk mencegah terjadinya gagal tumbuh dengan pemenuhan asupan zat gizi balita. Hasil analisis menunjukkan tidak ada hubungan bermakna antara status pekerjaan ibu dengan kejadian stunting balita pada keluarga miskin. Hasil ini sejalan dengan studi di Puskesmas Wonosari I yang menyatakan bahwa pekerjaan ibu tidak berhubungan dengan stunting (35). Ibu yang bekerja dapat mengurangi waktu interaksi dengan balita, namun hal tersebut tidak menurunkan peranan ibu dalam pengasuhan balita. Selain itu, ibu yang bekerja dapat membantu perekonomian keluarga sehingga daya beli terhadap makanan meningkat.

Jumlah balita dan jarak kelahiran juga tidak berhubungan dengan kejadian stunting balita keluarga miskin karena pada keluarga dengan jumlah balita sedikit (satu balita) dapat berarti bahwa balita tersebut merupakan anak satu-satunya atau balita memiliki interval kelahiran lebih dari 24 bulan atau ibu telah memiliki beberapa anak sehingga sudah berpengalaman dalam merawat anak. Selain itu, adanya saudara yang lebih tua dapat membantu dalam pengasuhan dan perawatan balita. Sementara itu, keluarga dengan jumlah balita yang banyak (lebih dari satu), meskipun akan mengakibatkan pengasuhan ibu ke anak menjadi terbagi (20), tetapi ibu sudah memiliki pengalaman dan pengetahuan dalam pengasuhan balita yang berperanan penting dalam pertumbuhan balita. Mayoritas responden penelitian ini hanya memiliki satu balita dalam keluarga dan jarak kelahiran yang lebih dari 24 bulan. Hasil studi lain menyimpulkan bahwa keluarga dengan jumlah anak balita lebih dari satu memiliki prevalensi stunting lebih besar dibandingkan dengan keluarga yang memiliki satu anak balita karena keluarga yang memiliki lebih banyak balita membutuhkan biaya yang lebih besar dan ibu mengalami kesulitan dalam mengurus anak serta tidak dapat bekerja untuk menambah pendapatan keluarga (16). Selain itu, interval kelahiran kurang dari 24 bulan memiliki prevalensi stunting lebih besar dibandingkan dengan interval kelahiran lebih dari 24 bulan (17). Hasil studi melaporkan prevalensi stunting anak dengan interval kelahiran kurang dari 24 bulan dari anak sebelumnya memiliki angka lebih besar $(23,4 \%)$ dibandingkan interval kelahiran lebih dari 24 bulan (19,83\%) (26).

Hasil penelitian ini menunjukkan hubungan signifikan antara urutan kelahiran dengan kejadian stunting. Model regresi logistik penelitian ini memperkuat hasil tersebut bahwa balita dengan urutan kelahiran pertama hingga kedua memiliki kecenderungan mengalami stunting 0,1 kali atau memiliki efek protektif jika dibandingkan dengan anak ketiga atau lebih. Studi lain juga melaporkan peningkatan kecenderungan stunting sebesar 4 kali lipat pada anak yang lahir pada urutan kelima atau lebih dibandingkan dengan anak yang lahir pertama $(\mathrm{p}<0,0001)(25)$. Salah satu karakteristik penyebab positive deviance pada populasi tinggi malnutrisi adalah jumlah paritas yang sedikit. Anak yang lahir pada urutan pertama dan kedua terbukti secara signifikan memiliki status gizi yang lebih baik (36).

Studi di Afrika menemukan bahwa urutan kelahiran secara signifikan berhubungan dengan kematian dan status gizi, dengan kondisi kesehatan anak yang lahir belakangan akan cenderung semakin memburuk. Hal ini karena urutan kelahiran yang semakin besar berhubungan dengan kejadian sunting, berat badan rendah, dan menerima asupan gizi yang tidak adekuat (37). Studi lain di India juga menemukan bahwa penurunan tinggi badan terjadi pada anak kedua dan meningkat sesuai urutan kelahiran. Hal ini karena di India terdapat suatu kecenderungan untuk preferensi pada anak laki-laki tertua dan perbedaan investasi yang tidak merata pada anak (intrafamily inequality) (38).

Hasil analisis multivariat menunjukkan bahwa keluarga dengan jumlah anggota keluarga banyak (lebih 
dari 4 orang) cenderung memiliki balita stunting 10,8 kali lebih besar jika dibandingkan dengan jumlah anggota keluarga sedikit, setelah variabel lain dikontrol. Jumlah anggota keluarga menentukan ketersediaan pangan dalam keluarga. Jumlah anggota keluarga yang bertambah menyebabkan pangan untuk setiap anak menjadi berkurang dan distribusi makanan tidak merata sehingga dapat menyebabkan balita menderita kurang gizi (14). Keputusan orang tua sangat mempengaruhi pertumbuhan anak. Pengalokasian atau pembagian sumber daya di rumah tangga, seperti makanan, akan berdampak pada kesehatan anak dan produktivitas saat dewasa nanti (39).

Penelitian di Guatemala menyimpulkan bahwa jumlah anggota keluarga menjadi prediktor kejadian stunting. Balita yang hidup di keluarga dengan jumlah anak empat atau lebih memiliki kecenderungan 3 kali lebih tinggi menjadi stunting dibandingkan balita pada jumlah anggota keluarga sedikit (40). Sejalan dengan hal tersebut, Indonesia telah menerapkan pembatasan kelahiran dalam rangka meningkatkan kesejahteraan ibu dan anak dengan gerakan Keluarga Berencana (KB) yang diatur dalam Undang-Undang Republik Indonesia (RI) Nomor 10 tahun 1992 yang diperbarui dengan UndangUndang RI No. 52 tahun 2009 tentang Perkembangan Kependudukan dan Pembangunan Keluarga. Pemerintah melakukan upaya pengendalian angka kelahiran dan penurunan angka kematian, pengarahan mobilitas penduduk, pengembangan kualitas penduduk pada seluruh dimensi, peningkatan ketahanan dan kesejahteraan keluarga, penyiapan, dan pengaturan perkawinan serta kehamilan sehingga terwujud pertumbuhan penduduk yang seimbang dan keluarga berkualitas. Selain itu, menurut Peraturan Menteri Kesehatan Nomor 39 tahun 2016 tentang Program Indonesia Sehat, salah satu indikator keluarga sehat dengan pendekatan keluarga adalah keluarga mengikuti KB.

Selanjutnya, hasil penelitian ini tidak menunjukkan hubungan signifikan antara pengeluaran pangan dengan kejadian stunting. Hal ini karena populasi yang diteliti kurang beragam dan terbatas pada golongan ekonomi bawah, yaitu keluarga miskin penerima PKH. Selain itu, pengeluaran pangan yang diteliti adalah pengeluaran pangan pada skala rumah tangga, tidak melihat pengeluaran maupun konsumsi pangan per kapita per bulan sehingga belum dapat menggambarkan secara jelas konsumsi pangan balita. Jumlah anggota keluarga yang bekerja dan berkontribusi menambah pendapatan keluarga juga memengaruhi kemampuan daya beli keluarga. Daya beli masyarakat dan pola konsumsi sangat dipengaruhi oleh faktor ekonomi (41). Kualitas dan jenis makanan diberikan kepada anak serta frekuensi pemberian makanan merupakan faktor penting yang berkaitan dengan dengan kejadian stunting pada anak (12).

Hasil analisis Chi-Square menunjukkan hubungan yang tidak signifikan antara pemanfaatan posyandu dengan kejadian stunting. Hasil penelitian ini sejalan dengan studi sebelumnya bahwa tidak ditemukan perbedaan proporsi stunting berdasarkan pemanfaatan posyandu di Kabupaten Jayapura. Hal ini karena proses terjadinya stunting telah terjadi sejak dalam kandungan. Gangguan pertumbuhan pada 1000 hari pertama kehidupan dapat memberikan dampak kerusakan yang permanen dan jangka panjang (irreversible) (42). Namun demikian, hasil analisis multivariat menemukan bahwa pemanfaatan posyandu berhubungan signifikan terhadap kejadian stunting setelah dikontrol variabel lain. Balita yang tidak rutin dan tidak pernah memanfaatkan posyandu akan memiliki kecenderungan 3,5 dan 5,2 kali mengalami stunting jika dibandingkan balita yang rutin memanfaatkan posyandu. Posyandu merupakan upaya kesehatan bersumberdaya masyarakat (UKBM) yang memberdayakan masyarakat serta mempermudah masyarakat memperoleh pelayanan kesehatan dasar sehingga mempercepat penurunan angka kematian ibu dan bayi, serta meningkatkan derajat kesehatan masyarakat. Salah satu fungsi posyandu adalah pemantauan pertumbuhan dan promosi kesehatan (27).

Hasil penelitian menemukan hubungan bermakna antara pengetahuan, sikap, pembinaan tenaga kesehatan, dukungan keluarga, dukungan tokoh masyarakat, dan dukungan kader, tetapi tidak ditemukan hubungan antara jarak posyandu dan dukungan teman terhadap perilaku ibu balita dalam menimbang anaknya ke posyandu (43). Selain itu, pendidikan orang tua, pekerjaan ayah, tingkat sosial ekonomi keluarga, dan morbiditas anak merupakan faktor risiko utama terhadap pemanfaatan posyandu (44). Sebuah program Mentor Mother - program berbasis pemberdayaan masyarakat dengan menerapkan konsep positive deviance - di Ethiopia menunjukkan hasil 
yang positif dalam meningkatkan kesehatan ibu dan anak. Program ini terbukti dapat menurunkan angka underweight pada balita (45). Penerapan konsep positive deviance, terutama di daerah kantong kemiskinan yang memiliki keterbatasan ekonomi, dapat dimanfaatkan oleh ibu balita untuk meningkatkan pengetahuan dan keterampilan menggunakan sumber daya lokal dalam mengatasi masalah stunting. Studi lain tentang positive deviance juga menunjukkan bahwa beberapa keluarga menggunakan bantuan pangan secara lebih baik dibandingkan dengan keluarga lain. Mereka dapat mengolah bahan makanan tersebut maupun menjualnya untuk membeli makanan lain (46).

Saat ini, pemerintah Indonesia melakukan pemberian bantuan sosial sebagai upaya mengentaskan kemiskinan melalui kebijakan Peraturan Presiden Republik Indonesia Nomor 63 tahun 2017 tentang Penyaluran Bantuan Sosial Secara Non Tunai. Salah satu program pengentasan kemiskinan adalah Program Keluarga Harapan berdasarkan Peraturan Menteri Sosial Nomor 1 tahun 2018. Hal yang harus diperhatikan adalah bahwa masyarakat seharusnya sadar bahwa pemberian bantuan tersebut bersifat sementara untuk mendorong kemandirian sehingga saat bantuan pangan berakhir, maka masyarakat dapat menemukan solusi bagi masalah kekurangan gizi tanpa ada ketergantungan pada bantuan pangan dari luar. Studi di Nigeria melaporkan bahwa peningkatan pemanfaatan pelayanan kesehatan dapat menurunkan angka stunting dan kurang gizi (47). Oleh karena itu, salah satu upaya untuk menurunkan angka stunting adalah menggabungkan program peningkatan ketahanan pangan keluarga dan peningkatan status gizi balita sebagai bagian dalam program penanggulangan kemiskinan.

Penelitian ini memiliki beberapa keterbatasan yaitu populasi balita berada pada keluarga miskin penerima PKH sehingga tidak bisa digeneralisasi pada seluruh populasi balita di Kota Palembang. Selain itu, penelitian ini tidak mengukur asupan makanan balita, konsumsi pangan per kapita per bulan, maupun efek dari pemberian bantuan PKH sehingga belum tergambar ketahanan pangan tingkat rumah tangga responden serta belum dapat mengevaluasi keefektifan pelaksanaan Program Keluarga Harapan (PKH) bagi penanganan stunting pada masyarakat miskin.

\section{SIMPULAN DAN SARAN}

Pendidikan ibu dan pemanfaatan posyandu merupakan faktor protektif terjadinya stunting, sedangkan jumlah anggota keluarga yang besar (lebih dari 4 orang) dan urutan kelahiran (anak ketiga dan selanjutnya) meningkatkan risiko stunting pada balita keluarga miskin penerima PKH. Program yang relevan untuk ditekankan atau dipersyaratkan bagi keluarga miskin penerima $\mathrm{PKH}$ adalah mengakses posyandu, terutama pada balita ketiga dan selanjutnya. Program lain yang sangat relevan untuk faktor risiko stunting berupa jumlah anggota keluarga yang besar (lebih dari 4 orang) dan urutan kelahiran lebih dari dua adalah Keluarga Berencana (KB) bagi masyarakat miskin penerima $\mathrm{PKH}$. Selain itu, program yang disarankan bagi masyarakat miskin penerima PKH untuk memutus mata rantai stunting adalah calon ibu dari keluarga miskin sebaiknya meningkatkan pendidikan formal minimal hingga SMA dengan mengikuti program wajib belajar 12 tahun.

Saran bagi penelitian selanjutnya adalah melakukan penelitian untuk menganalisis secara mendalam asupan zat gizi balita, ketahanan pangan keluarga serta mengevaluasi pelaksanaan program bantuan pemerintah bagi masyarakat miskin dalam keterkaitannya dengan kejadian stunting balita.

\section{Pernyataan konflik kepentingan}

Tidak ada konflik kepentingan dalam penelitian ini.

\section{RUJUKAN}

1. de Onis M, Branca F. Childhood stunting: a global perspective. Matern Child Nutr. 2016;12(Suppl 1):12-26. doi: $10.1111 / \mathrm{mcn} .12231$

2. Jesmin A, Yamamoto SS, Malik AA HA. Prevalence and determinants of chronic malnutrition among preschool children: a cross-sectional study in Dhaka City, Bangladesh. J Heal Popul Nutr. 2011;29(5):494-9. doi: 10.3329/jhpn. v29i5.8903

3. Solihin, R, Anwar, F, Sukandar D. Kaitan antara status gizi, perkembangan kognitif, dan perkembangan motorik pada anak usia prasekolah. Penelitian Gizi dan Makanan. 2013;36(1):62-72.

4. Tim Nasional Percepatan Penanggulangan Kemiskinan. 100 Kabupaten/Kota prioritas untuk intervensi anak kerdil (stunting): ringkasan. [series online] 2017 [cited 8 
Desember 2018]. Available from: URL: http://www.tnp2k. go.id/images/uploads/downloads/Binder_Volume1.pdf

5. Minarto, Ali PB, Octarina M, Wiranatakusumah A, Amanullah G, Romdiati H. Penguatan koordinasi pembangunan pangan dan gizi dalam penurunan stunting (Widyakarya Nasional Pangan dan Gizi XI). Jakarta: Bappenas; 2018.

6. Kementerian Kesehatan Republik Indonesia. Laporan nasional riskesdas 2018. Jakarta: Kemenkes RI; 2018.

7. World Health Organization. Nutrition landscape information system (NLIS) country profile indicators: interpretation guide. Geneva: WHO; 2012.

8. Kementerian Kesehatan Republik Indonesia. Buku saku pemantauan status gizi tahun 2017. Jakarta: Kemenkes RI; 2017.

9. Dinas Kesehatan Kota Palembang. Laporan pemantauan status gizi balita tahun 2017. Palembang: Dinas Kesehatan Kota Palembang; 2017.

10. Aridiyah FO, Rohmawati N, Ririanty M. Faktor-faktor yang mempengaruhi kejadian stunting pada anak balita di wilayah pedesaan dan perkotaan. Pustaka Kesehatan. 2015;3(1):163-70.

11. United Nations Administrative Committee on Coordination Sub Committee on Nutrition (ACC/SCN), International Food Policy Research Institute (IFPRI). 4th Report-The world nutrition situation: nutrition throughout the life cycle. Geneva: ACC/SCN \& IFPRI; 2000.

12. Hidayati L, Hadi H, Kumara A. Kekurangan energi dan zat gizi merupakan faktor risiko kejadian stunted pada anak usia 1-3 tahun yang tinggal di wilayah kumuh perkotaan Surakarta. Jurnal Kesehatan. 2010;3(1):89-104.

13. Wahdah S, Juffrie M, Huriyati E. Faktor risiko kejadian stunting pada anak umur 6-36 bulan di wilayah pedalaman Kecamatan Silat Hulu, Kalimantan Barat. Jurnal Gizi dan Dietetik Indonesia. 2015;3(2):119-30. doi: 10.21927/ ijnd.2015.3(2).119-130

14. Ramli, Agho K, Inder K, Bowe S, Jacobs J, Dibley M. Prevalence and risk factors for stunting and severe stunting among under-fives in North Maluku Province of Indonesia. BMC Pediatr. 2009;9(64). doi: 10.1186/1471-2431-9-64

15. Priyanti S, Syalfina AD. Determinan sosial terhadap kejadian stunting pada anak usia di bawah lima tahun. Jurnal Kebidanan. 2018;7(2):95-102. doi: 10.26714/ jk.7.2.2018.95-102

16. Agustian Y, Rusmil K, Solek P. Hubungan faktor sosio ekonomi dengan perawakan pendek anak usia 24-60 bulan. Sari Pediatri. 2018;20(2):106-14. doi: 10.14238/ sp20.2.2018.106-14

17. Fikadu T, Assegid S, Dube L. Factors associated with stunting among children of age 24 to 59 months in Meskan District, Gurage Zone, South Ethiopia: a case-control study.
BMC Public Health. 2014;14(800). doi: 10.1186/14712458-14-800

18. Ulfani DH, Martianto D, Baliwati YF. Faktor-faktor sosial ekonomi dan kesehatan masyarakat kaitannya dengan masalah underweight, stunted, dan wasted di Indonesia: pendekatan ekologi gizi. Jurnal Gizi dan Pangan. 2011;6(1):59-65. doi: 10.25182/jgp.2011.6.1.59-65

19. Hidayat TS, Jahari AB. Perilaku pemanfaatan posyandu hubungannya dengan status gizi dan morbiditas balita. Buletin Penelitian Kesehatan. 2012;40(1):1-10.

20. Sab'atmaja S, Khomsan A, Tanziha I. Analisis determinan positive deviance status gizi balita di wilayah miskin dengan prevalensi kurang gizi rendah dan tinggi. Jurnal Gizi dan Pangan. 2010;5(2):103-12. doi: 10.25182/ jgp.2010.5.2.103-112

21. Zeitlin M, Ghassemi H, Mansour M, United Nations University \& Joint WHO/UNICEF Nutrition Support Programme. Positive deviance in child nutrition - with emphasis on psychosocial and behavioural aspects and implications for development. Tokyo: United Nations University Press; 1990.

22. Bardosono S, Sastroamidjojo S, Lukito W. Determinants of child malnutrition during the 1999 economic crisis in selected poor areas of Indonesia. Asia Pac J Clin Nutr. 2007;16(3):512-26.

23. Rahayu A, Khairiyati L. Risiko pendidikan ibu terhadap kejadian stunting pada anak 6-23 bulan. Penelitian Gizi dan Makanan. 2014;37(2):129-36.

24. Monteiro CA, Benicio MHD, Conde WL, Konno S, Lovadino AL, Barros AJ, et al. Narrowing socioeconomic inequality in child stunting: the Brazilian experience, 1974-2007. Bull World Health Organ. 2010;88(4):305-11. doi: 10.2471/BLT.09.069195

25. Dekker LH, Mora-Plazas M, Marín C, Baylin A, Villamor E. Stunting associated with poor socioeconomic and maternal nutrition status and respiratory morbidity in Colombian schoolchildren. Food Nutr Bull. 2010;31(2):242-50. doi: 10.1177/156482651003100207

26. Zottarelli LK, Sunil TS, Rajaram S. Influence of parental and socioeconomic factors on stunting in children under 5 years in Egypt. East Mediterr Heal J. 2007;13(6):1330-42. doi: $10.26719 / 2007.13 .6 .1330$

27. Kusumawati E, Rahardjo S, Sari HP. Model pengendalian faktor risiko stunting pada anak usia di bawah tiga tahun. Kesmas: National Public Health Journal. 2015;9(3):24956. doi: 10.21109/kesmas.v9i3.572

28. Beal T, Tumilowicz A, Sutrisna A, Izwardy D, Neufeld LM. A review of child stunting determinants in Indonesia. Matern Child Nutr. 2018;14(4):e12617. doi: 10.1111/mcn.12617

29. Maxwell D, Levin C, Armar-Klemesu M, Ruel M, Morris S, Ahiadeke C, International Food Policy Research Institute. 
Urban livelihood and food and nutrition security in Greater Accra, Ghana. [series online] 2000 [cited 17 Mei 2019]. Available from: URL: https://www.who.int/nutrition/ publications/WHO_multicountry_\%20study_Ghana.pdf

30. Candra A, Puruhita N, Susanto JC. Risk factors of stunting among 1-2 years old children in Semarang City. Media Medika Indonesiana. 2011;45(3):206-12.

31. Gunardi H, Soedjatmiko S, Sekartini R, Medise BE, Darmawan AC, Armeilia R, et al. Association between parental socio-demographic factors and declined linear growth of young children in Jakarta. Med J Indones. 2017;26(4):286-92. doi: 10.13181/mji.v26i4.1819

32. Reyes H, Pérez-Cuevas R, Sandoval A, Castillo R, Santos JI, Doubova SV, et al. The family as a determinant of stunting in children living in conditions of extreme poverty: a case-control study. BMC Public Health. 2004;4:57. doi: 10.1186/1471-2458-4-57

33. Masrin M, Paratmanitya Y, Aprilia V. Ketahanan pangan rumah tangga berhubungan dengan stunting pada anak usia 6-23 bulan. Jurnal Gizi dan Dietetik Indonesia. 2014;2(3):103-15. doi: 10.21927/ijnd.2014.2(3).103-115

34. Ergin F, Okyay P, Atasoylu G, Beşer E. Nutritional status and risk factors of chronic malnutrition in children under five years of age in Aydin, a western city of Turkey. Turk J Pediatr. 2007;49(3):283-9.

35. Agustiningrum T, Rokhanawati D. Hubungan karakteristik ibu dengan kejadian stunting pada balita usia 24-59 bulan di wilayah kerja Puskesmas Wonosari I [Skripsi]. Yogyakarta: Universitas 'Aisyiyah Yogyakarta; 2016.

36. Pryer JA, Rogers S, Rahman A. The epidemiology of good nutritional status among children from a population with a high prevalence of malnutrition. Public Health Nutr. 2004;7(2):311-7. doi: 10.1079/PHN2003530

37. Howell EM, Holla N, Waidmann T. Being the younger child in a large African Family: a study of birth order as a risk factor for poor health using the demographic and health surveys for 18 countries. BMC Nutr. 2016;2:61. doi: 10.1186/s40795-016-0100-8

38. Jayachandran S, Pande R. Why are Indian children so short? the role of birth order and son preference. Am Econ Rev. 2017;107(9):2600-29. doi: 10.1257/aer.20151282
39. Rahman M. Association between order of birth and chronic malnutrition of children: a study of nationally representative Bangladeshi sample. Cad Saúde Pública. 2016;32(2):e00011215. doi: 10.1590/0102$311 X 00011215$

40. Sereebutra P, Solomons N, Aliyu MH, Jolly PE. Sociodemographic and environmental predictors of childhood stunting in rural Guatemala. Nutr Res. 2006;26(2):65-70. doi: 10.1016/j.nutres.2006.02.002

41. Saputri R, Lestari LA, Susilo J. Pola konsumsi pangan dan tingkat ketahanan pangan rumah tangga di Kabupaten Kampar Provinsi Riau. Jurnal Gizi Klinik Indonesia. 2016;12(3):123-30. doi: 10.22146/ijen.23110

42. Wasaraka YNK, Prawirohartono EP, Soenarto Y. Perbedaan proporsi stunting pada anak usia 12-24 bulan berdasarkan pemanfaatan pelayanan posyandu di Kabupaten Jayapura, Papua. Jurnal Gizi Klinik Indonesia. 2015;12(2):72-8. doi: 10.22146/ijen.23305

43. Djamil A. Faktor-faktor yang berhubungan dengan perilaku ibu balita menimbang anaknya ke posyandu. Jurnal Kesehatan. 2017;8(1):127-34. doi: 10.26630/jk.v8i1.409

44. Kalsum U. Child morbidity, level of parent's education, and accessibility to health facilities as factors affecting Posyandu utilization. Health Science Journal of Indonesia. 2013;4(1):27-31.

45. Tamir TA. Applying the positive deviance model in Ethiopia : the mentor mother project and its impact on childhood malnutrition in Holeta [Thesis]. Finland: University of Eastern Finland; 2017

46. Child Survival Collaborations and Resources (CORE). Positive deviance \& hearth: a resource guide for sustainably rehabilitating malnourished children. (Alih bahasa: Project Concern International). [series online] 2004 [cited 18 November 2018]. Available from: URL: https://coregroup. org/wp-content/uploads/2017/09/Positive-DevianceHearth-Resource-Guide-Indonesian.pdf

47. Agee MD. Reducing child malnutrition in Nigeria: combined effects of income growth and provision of information about mothers' access to health care services. Soc Sci Med. 2010;71(11):1973-80. doi: 10.1016/j. socscimed.2010.09.020 